\title{
The impact of marine current to Cu contents in Jiaozhou Bay
}

\author{
Dongfang Yang ${ }^{1,2,3, a}$, Sixi Zhu ${ }^{1,2}$, Fengyou Wang ${ }^{1,2}$, Mingzhong Long ${ }^{1,2}$ and \\ Xiuqin Yang ${ }^{1,2, b}$
}

${ }^{1}$ Research Center for Karst Wetland Ecology, Guizhou Minzu University, Guiyang 550025, China;

${ }^{2}$ College of Chemistry and Environmental Science, Guizhou Minzu University, Guiyang 550025, China;

${ }^{3}$ North China Sea Environmental Monitoring Center, SOA, Qingdao 266033, China.

adfyang_dfyang@126.com; 'bcorresponding author; cwangfy2001@yahoo.com.cn

Keywords: Cu; Distributions; Sources; Pollution level; Marine current; Jiaozhou Bay.

\begin{abstract}
Based on the investigation data on Cu contents in different seasons in 1983 in surface waters in Jiaozhou Bay, we analyzed the contents, pollution level and distributions of Cu. Results showed that $\mathrm{Cu}$ contents in May, September and October were 2.47-20.60 $\mu \mathrm{g} \mathrm{L}^{-1}, 0.86-4.86 \mu \mathrm{g} \mathrm{L}{ }^{-1}$ and 0.77-3.00 $\mu \mathrm{g} \mathrm{L}^{-1}$, respectively. The major souces of $\mathrm{Cu}$ were marine current, strem flow, shipping, the top of the islands and overland runoff, whose source strengths were $20.60 \mu \mathrm{g} \mathrm{L}^{-1}$, 2.20-10.57 $\mu \mathrm{g} \mathrm{L}^{-1}, 9.48 \mu \mathrm{g} \mathrm{L}^{-1}, 4.86 \mu \mathrm{g} \mathrm{L}^{-1}$ and $2.28 \mu \mathrm{g} \mathrm{L}^{-1}$, respectively. The influence of marine current to $\mathrm{Cu}$ contents in Jiaozhou Bay was strongest, indicated that the back ground pollution of $\mathrm{Cu}$ was the essential source in 1983.
\end{abstract}

\section{Introduction}

A large amount of $\mathrm{Cu}$-containing waste waters were generated along with the rapid increasing of industry and agriculture. The maine environment was finally polluted because ocean is the sink of various pollutants [1-2], and the pollution of marine environment could finally be harmful to human beings by means of food chain. Hence, it is necessary to understanding the pollution level and sources of $\mathrm{Cu}$ in the marine environment. Jiaozhou Bay is a semi-closed bay located in Shandong Province, eastern China, and has been polluted by various pollutants including $\mathrm{Cu}$ [1-2]. Based on the investigation data on $\mathrm{Cu}$ waters in different seasons in 1983, the aim of this paper was to analysis the content, pollution level, and sources of $\mathrm{Cu}$, and to provide basis for the research and pollution control contermeasures on $\mathrm{Cu}$ in Jiaozhou Bay.

\section{Materials and method}

Jiaozhou Bay $\left(35^{\circ} 55^{\prime}-36^{\circ} 18^{\prime} \mathrm{N}, 120^{\circ} 04^{\prime}-120^{\circ} 23^{\prime} \mathrm{E}\right)$ is located in the south of Shandong Peninsula, eastern China. The area and and average water depth are $460 \mathrm{~km}^{2}$ and $7 \mathrm{~m}$, respectively, yet the bay mouth is only $2.5 \mathrm{~km}$ (Fig. 1). This bay is surrounding by cities of Qingdao, Jiaozhou and Jiaonan in the east, north and south, and is connected with the Yellow Sea in the south. There are more than ten inflow rivers such as Loushan River, Licun River and Haibo River, all of which are seasonal rivers [3-4]. The investigation on $\mathrm{Cu}$ in surface waters in Jiaozhou Bay was conducted by North China Sea Environmental Monitoring Center in May, September and October 1983 (Fig. 1). The investigation and measurement of $\mathrm{Cu}$ were follow by National Specification for Marine Monitoring [5]. 


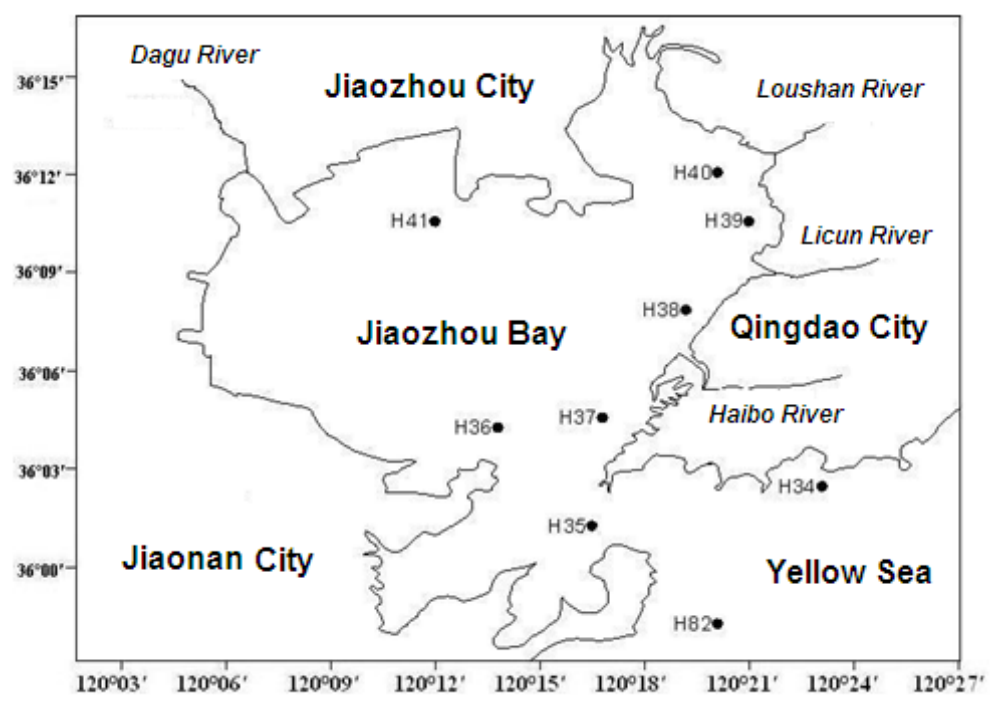

Fig.1 Geographic location and sampling sites of Jiaozhou Bay

\section{Results and discussion}

Contents and pollution levels of $\mathbf{C u}$. $\mathrm{Cu}$ contents in Jiaozhou Bay waters in May, September and October 1983 were 2.47-20.60 $\mu \mathrm{g} \mathrm{L}^{-1}, 0.86-4.86 \mu \mathrm{g} \mathrm{L}^{-1}$ and 0.77-3.00 $\mu \mathrm{g} \mathrm{L}^{-1}$, respectively.

In according to the guide line of Grade I $\left(5.00 \mu \mathrm{g} \mathrm{L}^{-1}\right)$, Grade II $\left(10.00 \mu \mathrm{g} \mathrm{L}^{-1}\right)$ and Grade III (50.00 $\mu \mathrm{g} \mathrm{L}^{-1}$ ) for $\mathrm{Cu}$ in National Standard of China for Seawater Quality (GB3097-1997), this bay was sightly contaminated by $\mathrm{Cu}$ in September and October in 1983, while was moderate contaminated in May (Table 1).

Table 1 The pollution level of Cu in Jiaozhou bay in May, September and October 1983

\begin{tabular}{|c|c|c|c|}
\hline & May & September & October \\
\hline Content $/ \mu \mathrm{g} \mathrm{L}^{-1}$ & $2.47-20.60$ & $0.86-4.86$ & $0.77-3.00$ \\
\hline Grade & I, II and III & I and II & I and II \\
\hline
\end{tabular}

Horizontal distributions of $\mathbf{C u}$. In May, high value of $\mathrm{Cu}$ contents were occurred in Site H34 and H82 (1.75 $\left.\mu \mathrm{g} \mathrm{L}^{-1}\right)$, and there was a high value region aound the two Sites. A series of parallel lines were forming and were decreasing fom the out side of the bay $\left(20.60 \mu \mathrm{g} \mathrm{L}^{-1}\right)$ to the inner side of the bay $\left(2.47 \mu \mathrm{g} \mathrm{L}^{-1}\right)$ along with the direction of the marine current (Fig. 2). Another high value region was occurred around Site $\mathrm{H} 40\left(10.57 \mu \mathrm{g} \mathrm{L}^{-1}\right)$ near the estuary of Loushan River in the northeast of the bay. A series of semi-concentric circles were forming and were decreasing from the high value center to the bay mouth $\left(4.75 \mu \mathrm{g} \mathrm{L}^{-1}\right)$ along with the flow direction of the river. There was also a high value region around Site H37 in coastal area in the bay mouth $\left(9.48 \mu \mathrm{g} \mathrm{L}^{-1}\right)$, and a series of semi-concentric circles were forming and were decreasing from the high value center to the bay mouth $\left(2.94 \mu \mathrm{g} \mathrm{L}^{-1}\right)$ (Fig. 2). In September, a high value region was formed around Site H35 (4.86 $\mu \mathrm{g} \mathrm{L}^{-1}$ ) in the bay mouth. A series of semi-concentric circles were forming and were decreasing from the bay mouth to the north of the bay $\left(0.86 \mu \mathrm{g} \mathrm{L}^{-1}\right)$ and the out side of the bay mouth (1.43 $\left.\mu \mathrm{g} \mathrm{L}^{-1}\right)$ (Fig. 3). Another high value region was occurred around Site H38 between the estuaries of Licun River and Haibo River, and a series of simi-concentric circles were froming and were decreasing from the high value center to the north of the bay (0.86 $\mu \mathrm{g} \mathrm{L-1)}$ (Fig.3). In October, a high value region was formed around Site H40 (3.00 $\mu \mathrm{g} \mathrm{L-1)}$ in the estuary of Loushan River in the northeast of the bay. A series of semi-concentric circles were forming and were decreasing from the high value center to the bay mouth $(0.77 \mu \mathrm{g}$ L-1) (Fig. 4). Another high value region was occurred around Site H34 out side the bay mouth (2.28 $\mu \mathrm{g} \mathrm{L-1)}$, and a series of simi-concentric circles were froming and were decreasing from the high value center to the south of the bay mouth 
(1.75 $\mu \mathrm{g} \mathrm{L-1)} \mathrm{(Fig.} \mathrm{4).} \mathrm{The} \mathrm{horizontal} \mathrm{distributions} \mathrm{of} \mathrm{Cu}$ contents indicated that there were different pollution sources of $\mathrm{Cu}$ in the bay.

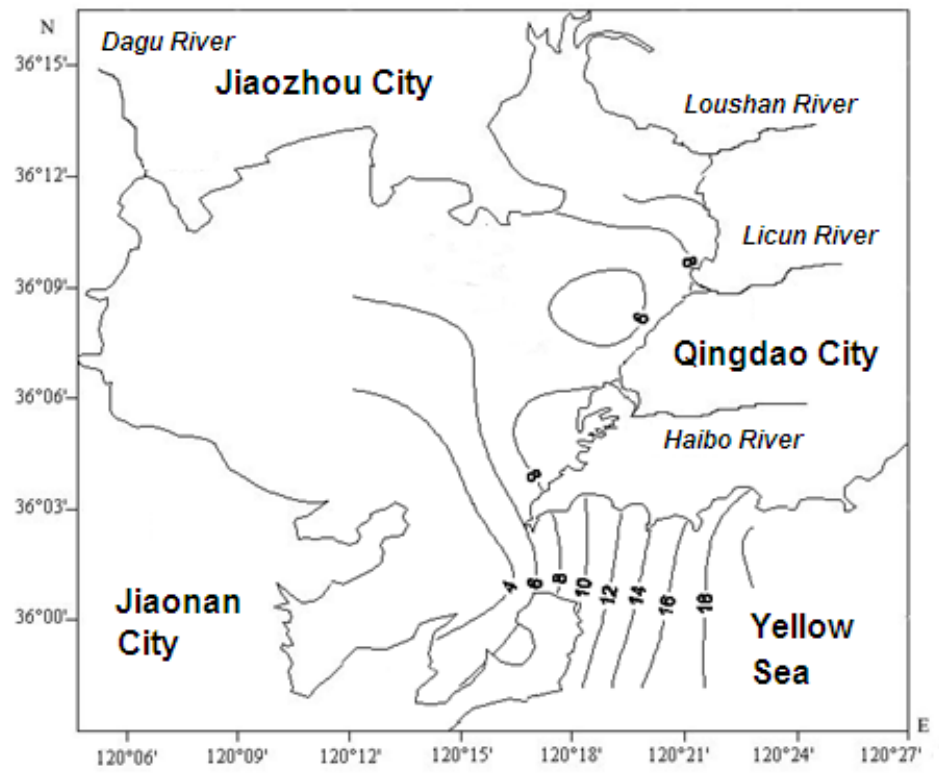

Fig. 2 Horizontal distribution of Cu in surface waters in Jiaozhou Bay in May 1983/ $\mu \mathrm{g} \mathrm{L}{ }^{-1}$

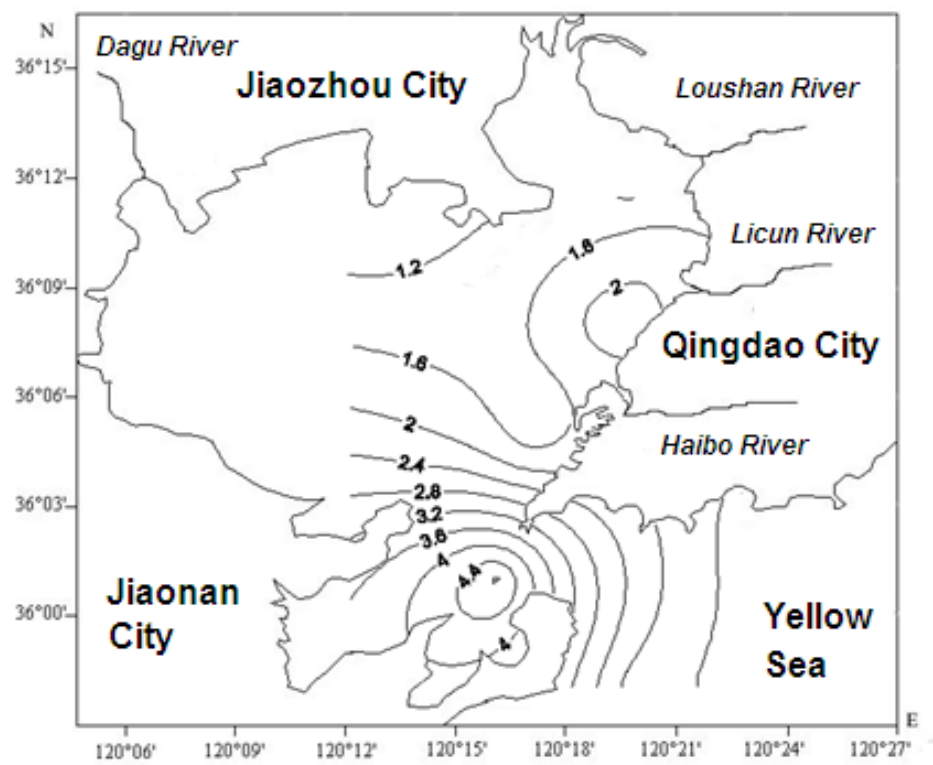

Fig. 3 Horizontal distribution of $\mathrm{Cu}$ in surface waters in Jiaozhou Bay in September 1983/ $\mu \mathrm{g} \mathrm{L}{ }^{-1}$

Pollution sources and source strengths. In according to the horizontal distributions of $\mathrm{Cu}$ in surface waters, we found that there were some relative high value regions in different seasons. In May, $\mathrm{Cu}$ contents were decreasing from the out side of the bay to the center of the bay along with the direction of the marine current, indicated that marine curent was one of the major source of $\mathrm{Cu}$. Meanwhile, there was high value regions near the estuaries of the major rivers in the northeast of the bay, indicated that stream flow was another major source of $\mathrm{Cu}$ in May. In September, there was a high value region in the coastal area in the bay mouth, indicated a part of $\mathrm{Cu}$ was dischanged from the top of the islands. High value regions were also occurred in the estuaries of the river in the northeast of the bay, indicated that stream flow was also one of the major sources of $\mathrm{Cu}$ in September. In October, high value regions were also occurred in the estuaries of the river in the northeast of the bay, and in coastal area in the northeast of the bay, indicated that stream flow and overland runoff were major source of $\mathrm{Cu}$. Meanwhile, a high value region was occurred the the north out side the bay, indicated shipping was also one of the major source of $\mathrm{Cu}$. Hence, it could be 
concluded that the major sources of $\mathrm{Cu}$ were marine current, strem flow, shipping, the top of the islands and overland runoff, whose source strengths were $20.60 \mu \mathrm{g} \mathrm{L}^{-1}, 2.20-10.57 \mu \mathrm{g} \mathrm{L}{ }^{-1}, 9.48 \mu \mathrm{g}$ $\mathrm{L}^{-1}, 4.86 \mu \mathrm{g} \mathrm{L}^{-1}$ and $2.28 \mu \mathrm{g} \mathrm{L}^{-1}$, respectively (Table 2). We defined marine current was natural source, while the other sources were anthropogenic sources, it was clear that the impacts of natural source were responsible for Cu pollution in 1983.

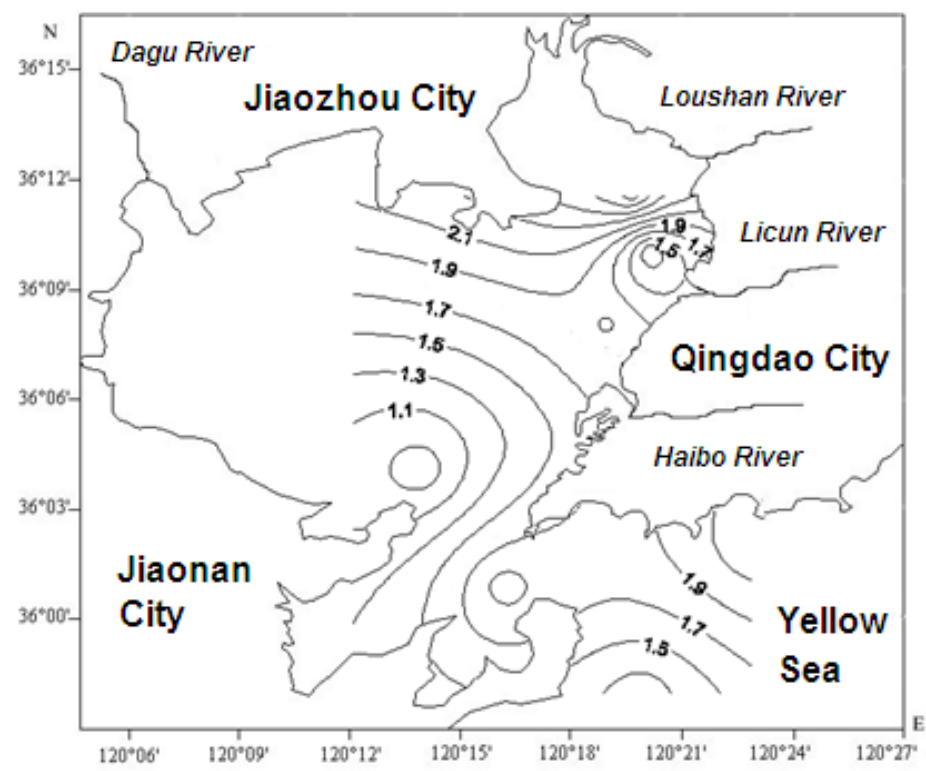

Fig. 4 Horizontal distribution of Cu in surface waters in Jiaozhou Bay in October 1983/ $\mu \mathrm{g} \mathrm{L}^{-1}$

Table 2 Source strengths of different pollution sources for $\mathrm{Cu}$ in Jiaozhou bay

\begin{tabular}{|l|c|c|c|c|c|}
\hline \multicolumn{1}{|c|}{ Source } & $\begin{array}{c}\text { Marine } \\
\text { current }\end{array}$ & Stream flow & Shipping & $\begin{array}{c}\text { The top of } \\
\text { the island }\end{array}$ & $\begin{array}{c}\text { Overland } \\
\text { runoff }\end{array}$ \\
\hline $\begin{array}{l}\text { Source } \\
\text { strength } / \mu \mathrm{g} \mathrm{L}{ }^{-1}\end{array}$ & $2.58-3.38$ & $2.25-2.60$ & 1.90 & 2.50 & 1.75 \\
\hline
\end{tabular}

\section{Conclusions}

$\mathrm{Cu}$ contents in May, September and October were 2.47-20.60 $\mu \mathrm{g} \mathrm{L}^{-1}, 0.86-4.86 \mu \mathrm{g} \mathrm{L} \mathrm{L}^{-1}$ and 0.77-3.00 $\mu \mathrm{g} \mathrm{L}^{-1}$, respectively. This bay was sightly contaminated by $\mathrm{Cu}$ in September and October in 1983, while was moderate contaminated in May. The major souces of $\mathrm{Cu}$ were marine current, strem flow, shipping, the top of the islands and overland runoff, whose source strengths were 20.60 $\mu \mathrm{g} \mathrm{L}^{-1}, 2.20-10.57 \mu \mathrm{g} \mathrm{L}{ }^{-1}, 9.48 \mu \mathrm{g} \mathrm{L}^{-1}, 4.86 \mu \mathrm{g} \mathrm{L}^{-1}$ and $2.28 \mu \mathrm{g} \mathrm{L}^{-1}$, respectively. The impacts of natural source were responsible for $\mathrm{Cu}$ pollution in 1983.

\section{Acknowledgement}

This research was sponsored by Doctoral Degree Construction Library of Guizhou Nationalities University, Education Ministry's New Century Excellent Talents Supporting Plan (NCET-12-0659), Education Ministry's New Century Excellent Talents Supporting Plan (NCET-12-0659), Project of Outstanding Technological Educators of Governor of Guizhou ([2012]71), Project of Low Carbon Technology Plan of Guiyang (2012205]), Project of Science and Technology Foundation of Guiyang (LKM[2012]05), Special Research Projects of High Level Talents of Guizhou Province (TZJF-2011-44), the China National Natural Science Foundation (31560107) and Research Projects of Guizhou Nationalities University ([2014]02), Research Projects of Guizhou Province Ministry of Education (KY [2014] 266), Research Projects of Guizhou Province Ministry of Science and Technology (LH [2014] 7376). 


\section{Reference}

[1] Yang DF, Miao ZQ, Song WP, et al.: Chen ST, et al.:, Advanced Materials Research, Vol. 1092-1093 (2015), p. 1013-1016.

[2] Yang DF, Chen Y, Gao ZH, et al.: Chinese Journal of Oceanology and Limnology, Vol. 23 (2005), pp. 72-90.

[3] Yang DF, Wang F, Gao ZH, et al.: Marine Science, Vol. 28 (2004), p. 71-74. (in Chinese)

[4] State Ocean Administration. The specification for marine monitoring: Beijing, Ocean Precess, (1991). 